\title{
ANALYZING THE ORGANIZATIONAL QUESTIONS OF THE ELITE YOUTH ACADEMIES BY THE CASE STUDY OF FOOTBALL ACADEMY OF DEBRECEN
}

\author{
Zoltán Szalánczi \\ University of Debrecen, Faculty of Economics and Business, Institute of Sports Management \\ 4032, Debrecen, Böszörményi street 138 \\ szalanczi.zoltan@econ.unideb.hu
}

\begin{abstract}
Thanks to the effect of the resources flown in to the youth football, the previous, and more simpler structural scheme of the clubs went under a transformation. I will analyse the operation of the youth sport enterprises as economic companies, and the organizational scheme with the most important managerial questions faced in the firm. This will be based on the case study of the Football Academy of Debrecen. In the first part of my publication, I will investigate the evolution and the importance of the sport enterprises, with the relevant scientific literature. In the second part I will discuss the structural scheme of the Football Academy of Debrecen with the analysis of the separate departments. I will search for the differences between the youth sport enterprises and the organisations who are operating as a professional football club.
\end{abstract}

Keywords: non-profit company, sports enterprise, structural scheme, youth development (JEL Classification: Z2)

\section{INTRODUCTION}

Thanks to the great potential and fast development of the sport sector, professionally operated clubs started to appear in the last quarter of the XX. century. These clubs worked like an economical company with profit- and benefitoriented functions in the frame of the national championships. In the evolution of the professional sport three factors were determinate (DOWNWARD et al. 2009):

a. Development in the organizational part of championships and competitions

b. Presence of paying spectators and the development of the available infrastructure and sport consumption attitude

c. Creation of properly formalized championships

The sport-science and the economy grew separately for a long time, but next to the nature-science side, the social aspects of the sport gained ground increasingly. The evolution of the business part in the sport was the base of the fact, that there is no such thing as modern sport-science without economic theories. A lot of consumer and producer decisions became analyzable with the methods given by the economy, because the discipline handling the conditions, alternatives, and results of these decisions investigate the consumption and production of these bare resources. It became clear, that the attendants of the sport market meet these decisions on a daily basis. It is an important part of the economy to follow up these procedures, where the exchange transactions happen between people and organizations. These procedures are the input of the analysis. In economical manner, market is the mechanism, where the concrete and potential participators of the sector find and change their products or services between each other. The central elements of the process are the supply, demand, price, and income (ÁCS, 2015).

The aim of this research is to analyze the organizational structure of an elite football academy and also to show the similarities and differences between the youth sport enterprises and profit-oriented professional futball organisations.

The business aspect of the sport is a largely nation and sport-specific phenomenon. It is in close relation with the internal attributes of the concrete sport (rules, organization, media-capability, etc.) and in other hand there is an impact from the nations economical system, development level and cultural traditions (ANDRÁS, 2003).

A research from Ibrahim (2009) confirmed, that the advancement in the economy and the successfulness in the sport do not come together. We cannot say, that the nation 
who has a more advanced economical system has better results in the sport events than other undeveloped countries. This research highlighted that we have to separate successes achieved in the financial and in the sport-technical aspects, and in the future, we have to deal with the economic efficiency separated from the results „on the pitch”.

The presence and amplification of the business in the sport can be realized in the next general steps. The starting point can be found in the popularity of the sport, which is determined by the amount and potential growth of the number of spectators. This basis amplifies the interests of the companies who want to raise their media and marketing activities. These factors are the ones, whose start the change in the sports traditional organizational structure, which comes with new stakeholders on the markets of the sport sector. These new participants can be leagues, agencies, event-organizing companies, who generate new cash flows. Thanks to the development, tools shown up for the coordination of the market (ANDRÁS, 2003):

a. business coordination, business technics

b. specialization: agents, mediators

c. new products: royalties, transfers

d. sport organizations transforming into business organizations

Nowadays, the sport sector is one of the biggest form of entertainment. The market had an impact on the mostly mediacapable sports. The consumer became determinate with the penetration of the business into the sports. We can talk about business in the sport, when specialized companies satisfy the consumer demands connected to the sporting or watching sport events. The base of this is the suitable organizational structure and the change in the management from the sport-oriented leadership to the company-oriented type. The increase of the solvent demand on the market just amplified these effects. The interesting and media-capable sports, followed by lot of people gained the interest of the company sphere, who wanted to raise their marketing activities, with the fact, that they can be a cheap and alternative advertising space. Thanks to these effects, a lot of money flowed in to the sport-market. This trend changed the traditional income-structure of the sport clubs, and also had an impact on their interior values. With the influence of the commercialization, the sport companies had to adapt to the changed environment of the market. In a couple of sports, the formerly elitist, amateur aspect was changed to the business guided aspect. The closed, socially isolated approach became open, and the game changed into business. Even so, this process is still running, the battle between different values still alive. The showing of the business in the sports can be analyzed in different aspects. An important step was the technological development, because sudden expansion of the communication and informatics made possible to settle with the geographical borders. Due to this, the sport events far from each other became potential rivals on the domestic market. The inflow of the great amount of capital also induce changes in the rules of the game. The interest towards the sports, and the income linked to this were growing together with the investments and working costs of the companies.
The components of these are the arisen (sportsman) salaries, the growing entertainment supply, and the highly expansive technological and sport-science apparatus. It is more and more in the interest of the sport-companies to "keep" their popular players, as bare resources on the pitch. The business aspect mostly extended out in the "spectacle" sports. The leisure sports realized a change like all the other companies in the business world.

Probably the reason for this big difference between leisure and spectacle sports, and also thanks to the media these sports are important parts of the entertainment sector. Inside the media, the development of the television coverage was the biggest indicator of the commercialization of the sports. The presence of the television was the key to gain the interest of the consumers. The media is the biggest bearer of the business possibilities in the sports, so we have to understand it through the interests of it. It is ascertainable, that many people's free time is pledged to the television, and it made, and helped to spread the "passive sport".

Only a few sports became a "spectacle sport" (ÁCS, 2015). On occasion of the traditional sports, it is an important aspect for us to see, what are the characteristics to call them media capable.

Five attributes were defined (ÁCS, 2015) to help us decide these sports:

a. appropriate arrangement in space and time

b. understandable and simple rules

c. spectacular

d. high spectator interest

e. it can be broadcasted without special skill and equipment

The media also made a new product in the sports. Intangible assets started to appear connected to the sport-events. From these assets the most significant is the broadcasting rights. According to Gálik and Urbán (2009) a new dimension came inside to the traditional classification of sports. We have to differentiate "made for television" sports also, what are only watchable for us through the television.

According to the definition, the company is the frame of the business enterprise. The company appears as a legal personality, like an organization, and we have to decide if it a business enterprise or not. It can be decided simply, sith it takes a form of any business organization, we can talk about a business enterprise. The business economics made a multiphasic and coherent criteria system, which can be the base of the decision (CHIKÁN, 2003):

a. the organization is independently achieving their goals

b. it works profit-oriented

c. it operates risk fully

d. it operates on an actual market

In this aspect, the business organization is a human activity, which has the basic goal to realize profit with the satisfying of the consumer demands (CHIKÁN, 2003). If we want to phrase this definition in the case of sport companies, the sport company is an enterprise, who wants to satisfy the consumer demands realized in the limits of sports with the attainment of profit. 
To know, if these conditions exist, it is recommended to inspect these factors more closely on the grounds of sports. About the risky operation, according to Bayer (2006), such high risk shows up only in the entertainment industry, because the fluctuant individual performances what go along with insecurity. Towards this, in theory, the high risk comes with high profit, and it can be suitable for the specific preferences of the investors, like the goal of achieving publicity.

It is important to examine the company in the aspect of long term profitability, but it is not necessary to handle this attribute in priority, because the sport satisfies a demand in each case, what is regarded the most determinate benefit, thanks to the commitment.

The next step in the analysis of the sport companies can be the case of independency. It is important to know if the company can deliberate their environment in their own aspects, and can it make the decisions based on it, because on this special market other participants can affect the conditions. It is important to examine the question of the actual market. We can realize a well operating price-mechanism in the input and output also. The nonprofit organizational background formed in the 19-20. decade in the sports. Usually they were social organizations, and this was the first step in the forming of the national sport associations. These associations worked like a labour organization for the sport clubs, and later on, their cooperation was the base in the forming of the international associations (ÁCS, 2015). According to András (2002), the sport companies are enterprises, what give the frame of the business organizations. They are usually formed as a business company. We can analyze these companies in narrow or in wide range. If we choose the narrow range, those companies belong here, who only have the contact with the final consumer. If we investigate in a wider range, those companies belong to the group, who are much farther in the supply chain. Thanks to these specialties, they can realize profit form five separate, but closely related markets.

Specialty of the companies in the sport sector can also be the contradiction of the goal-oriented operation. In one hand, the goal is the successfulness in the sport, but in the other hand, the profitability of the business operations can also be the main aspect. It is the objective of the management to find the balance between these goals (ÁCS, 2015).

To secure this balance, Chikán (2003) noticed a so called double value proposition, where the owner and the client creates values in the same process.

The sport companies who operate business oriented have these main markets (ANDRÁS, 2003):

a. consumer market

b. broadcasting rights market

c. sponsors market

d. merchandising market

e. players market

As a matter of the composition of the market, the consumers market is the local attendants and the consumers connected in other kind of mediums. Of course, these are not only the attendants, we have to note also the media and the companies with marketing goals.
The market for the broadcasting rights give already the biggest and most important part of the intangible assets, with the meaning, to give broadcast from a sport event, what are available only with the entrance fee (ANDRÁS, 2002). The value of this right is affected by the media-capability of the sport. The owners of the rights of the sport events are on the seller's side, who are mostly the organizers of the championships or tournaments, and the customers are the television companies, who buy these intangible assets in packages from them.

On the sponsors market firstly sport equipment companies started to appear, and in the 1970's this progress started to became more significant. According to Kassay (2010), the sponsoring is a two-sided business connection with rights and responsibilities bounded for economic successes. This kind of cooperation can boost the marketing activities of the company, and also the selling of the sport goods. Nowadays this relationship became one of the most important income resource for a company on the sports market.

The merchandising appeared on the grounds of the sport in the 1980's, with the point to increase the income of the sport companies with the selling of products decorated with the colors or logos of the clubs. The merchandising has a great effect on the selling of the club's products with the influence on the consumer decisions. It can affect these decisions with local marketing tools, guaranties, and others mediums. In our days we can enlist the merchandising as a tool for promotion and motivation (DÉNES, 1998).

The players market is a special labor market with a specific intangible asset, where the right of the player is defined, and it can be granted for a limited time between organizations. It is an intangible asset bounded to a person (sportsman), and it is overly including his capabilities allied with the sport (ANDRÁS, 2003).

The fast adaptation to the changes is an organic part of a company's strategy in the competitive industry. This is a typical tendency also in the professional sports as part of the entertainment sector, where services are provided. If we use the STEP (Social, Technology, Economic, Political) analysis to present it, it can be seen, in the economic aspect, the global economy, like the frame of the sport business and sport business operations (CHIKÁN, 2003), the economic recession (crises, national/regional pressures), and the changing systems are the main challenges for a company (ANDRÁS, 2011). The professional sport and the correlation of the business globalization is not a new concept. According to the interpretation of globalization in the business sector, in the professional sports, the decisions of the managers weigh the possibilities occurring worldwide. These decisions stay between the borders of Europe, but the expenditure of this frontier can come in a short time (CHIKÁN, 2003). It can be seen from these approaches, the managers are in the center of the globalization processes. They are making decisions according to the local, but also for the global trends like input or output processes. The markets of the professional sports (ANDRÁS, 2004) are also global, but only in different amount. The professional sport and their media-capable versions, the so-called spectator sports became the part of the entertainment sector, so they were 
also affected in 2008 by the economic recession (ANDRÁS, 2011). According to the IEG Sponsorship Report, the classical marketing activities like advertisement and public relations had a downfall, but the sport sponsoring is growing after a small recoil (ÁCS, 2015).

In the last period of time, the role of the human resource has a significantly increased value in the economic and also in the social processes. Nowadays the people became the most significant resource in the aspect of successfulness and economic efficiency in a company. The fast-changing environment in the consumer and provider society, and other factors resulted an increase in the role of the human resources against other natural and economic resources (SZABÓ and BERDE 2007)

The modern managers see their employees as the most valuable assets in the organization. It has a key role in the success of a company to effectively invest and develop their intellectual capital. According to national and international researches, it can be seen, that the human resources and their management are crucial part of raising a company's competitiveness and performance in the business sector. The human capital has a significantly bigger value, then a group of people working for the organization. It has his own added value, what the employees bring for the organizational success of the company (DAJNOKI, 2015).

The human capital is a value based on the skills, knowledge and working-, and life experiences of the organizational members. It is also the collective value of motivation. Sometimes it is called as intellectual- and knowledge capital, emphasizing the importance of the human thinking, knowledge, creativity, decision-making, in the operation of the companies (KAROLINY and POÓR 2010).

If we would like to understand the role what the selection of the right human resources weighs in the sports, I would like to bring up this quote: "The human resources have more to do with the sports than we think. The scientific recruitment process finding the talents and reinforcements in the sport sector can be compared to the business sector - had his remark foremost" in the Present and future of HR in the sports conference Antal Gubicza, who had successes as head of organizations in karate, wrestling, and skiing" (PARASZT, 2008). Nowadays we have to handle the value of human resources seriously as the sport became an important business. It is a part of our everyday entertainment since the spectacle-sports can be found in the television or other mediums. In this sector, with this high business potential, the human resources really have a special value, because of fact, great sport performances are made by "ordinary" people. The person, who can make an outstanding performance is a bare resource on the market of sport companies.

It is also an important specification for a company operating in the sport sector, is the contradiction between the economic and sports success. In one hand the goal is to achieve success in the sport events, but in other hand the profitability is an important aspect also.

It is the objective of the management to serve the owners expectations and find the balance between these two goals (ÁCS, 2015). The need for sport and also economic successes reflect back in the organizational scheme of these companies (BÁCSNÉ, 2015/B, 2015/C, 2016). Companies operating the teams in the first division of the Hungarian Football Championship are corporations in one-third, and the two-third of them are limited-liability companies. In the Ltd. form, the most important part is the general assembly. The company is driven by the managing director, who is given the employing rights. The major, prescribed parts of the corporations are: general assembly, directorate, supervisory board, and the auditor. Beyond these, in the two organizational structure there are marketing, PR/Communications, logistics and technical departments also. In the Ltd. structure, the sport-technical department works separately, and a financial director helps the managing director. In the corporation, these tasks are driven by the club-director. The organizational parts are built in a functional way, so the division of labor is base of the creation of a department (BÁCSNÉ, 2017).

\section{MATERIALS AND METHODS}

The data was collected for the research by an interview with the technical director and the managing director of the Football Academy of Debrecen. The interview was made personally at the training center of the club, and the questions were based on the strategical and organizational aspect of the elite academy controlled by them.

\section{RESULTS AND DISCUSSION}

The nonprofit character has not only had an effect for the framework of the resources, but also on the organizational structure. Typically, the sport-technical questions are in the center out of the youth development objectives, with the support of the multidiscipline training program. It can be seen from the organizational structure, the Football Academy of Debrecen is separated for five departments, and they significantly differ from the structure of a profit-oriented company. The biggest difference is the absence of a separate legal, marketing, and financial department (1).

Figure 1: The organizational structure of the Football Academy of Debrecen

Source: Own illustration

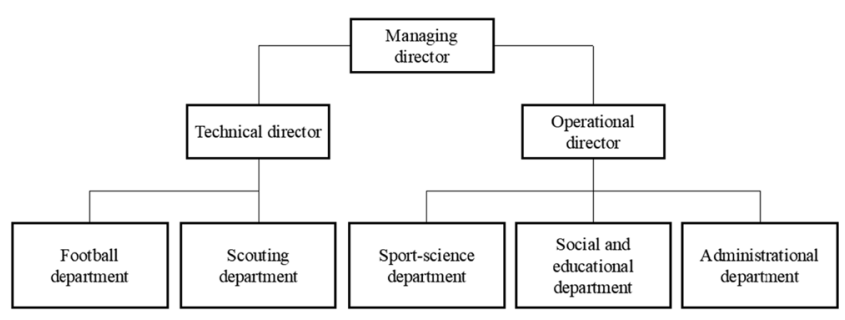

In the leading of the company, three persons have a key role. The role of the managing director is to probate the interest of the owners, and the legal representation of the company. The clear demand from the DVSC Football Corporation as owner, is the flow of home grown players in to the first team, and to 
build a base for the youth players. The influence of DVSC on the Academy is unquestionable. The success of a youth sportoriented company is not measurable by financial indicators. It is related to the number of homegrown players integrated in the first team. The employees under the managing director are the technical and operational directors. These two persons coordinate the five departments directly. It is a characteristic of the linear organizations, that the functional and technical connections overlap, and the regulations of the objectives and authorities are clear (MUSINSZKI, 2012). In this context it can be seen, the control of each department is in the hand of a director with relevant technical knowledge. The sport-technical questions, like the development of players, scouting, coordination and evaluation of the coaches are the responsibilities of the technical director. Securing the conditions for the "work on the pitch", and controlling the organizational parts are the main tasks for the operational director.

The complexity of the work in the football department is given by the need to synchronize the development strategy of the different age groups. The teaching of the club's football philosophy starts in the youngest age groups, and they have to receive a complex, up-to-date development structure to be able to reach achievements in the future. The success of the academy is mostly depending on the performance of this department. A different kind of development is needed instead of the in a profit-oriented sport company. The work in the other departments are assigned under this section. The prime objective for the scouting department is to find and integrate the talented players in to the development system, with the usage of the defined player profiles. The controlling rights of the technical director is the important base of this department.

As the matter of the departments controlled by the operational director, they are also working to make the players development program easier to organize. The social and educational department is aiming to make the school and dormitory integration smoother, and to help the players with out of sport activities. It is important to have time for the studies next to the trainings and matches, to give them a chance for a career, if they don't succeed in the sport. The sport-science department is also in the authority of the operational director because the performance-diagnostics, mental, medical, and also the rehabilitation activities help the adequate development of the players, while the administrational and logistics department handles the actions connected to the competitions, contracts and player licenses. The financial management is also integrated in this section, because the financial administration is largely coming from accounting the received subsidies thanks to the nonprofit character.

In the organizational structure of the analyzed football academy - even in the structure of the income - the nonprofit elements dominate, but as the owner's objectives, the integration of the players to the first team direct the interest to the role of the business goals. These goals are the possibilities to develop quality players with serious market value.

In the last period, the Football Academy of Debrecen fell over a serious organizational transformation. The expansion in the sport-technical possibilities was necessary. For now, all the youth teams have two trainers, what is the base of quality work on the pitch, and there was a raise in the number of the specialists. The academy appointed employees like sport-psychologist, dietitian, performance and rehabilitation coaches, but this was not the biggest change in the life of the organization. In 2012, the managing director was the same person, who was responsible for the technical director position, but these tasks in each job needed a whole man. Thanks to the money invested in the youth sport, the budget of the company grown, and the legal background of the accounting was in need of a qualified financial staff. The daily operational work had to be separated from the development "on the pitch". To suit this, they had to completely reorganize the academy. They needed to separate the responsibilities and form departments with short-, medium-, and long-term objectives. To separate the control of the development strategy and the daily operation of the academy, the company had to appoint an operational director. His main objective was to take the tasks off from the shoulders of the technical-director, what are beyond his competences. The second big step in the academy's life was to terminate the "double-functions" in the staff, so everyone can focus on their objectives written in their job description and contract. Formerly the coaches, but also almost all the other employees had more than one functions in the company, mostly because of the financial possibilities. Besides the separation of the activities, the number of the employees almost doubled, sith an organization with this much budget, and number of players, needs more people for one task, for example the financial or coaching staff. The last change in 2018 was also in the management because of the improvement of the connection with the owners. With this modification, the technical-director only have to focus on the development strategy, and the questions about the work on the pitch. The managing director responsibilities are now belonging to a person who is a qualified and experienced business expert. This change in the management structure helps the organization to clarify the responsibilities and to remove the double functions.

With the development of sports, the economical conduct of the companies became common. The for-profit enterprises are part of the sport thanks to the high amount of money flown in to the sector, but we can find a notable difference between the organizational structure of nonprofit company like a youth academy. The major markets don't appear, or they alter because of the nonprofit nature, and this transformation have an effect on the structure also.

If we analyze the structure of the Football Academy of Debrecen, we can see the differences compared to the for-profit companies. The departments primarily create the conditions for the development program, while the legal, economic and marketing departments are missing, or they are integrated in another section. In total despite of these differences in the income, and in the organizational structure there are elements, what are guided by the owner's economic interest, so they are financially grounded.

The analyzed company's cooperation with the first team 
of DVSC is unique in the nation, thanks to the high number of players integrated to the professional level. This can be a good example for other clubs and not only on the development strategy level, but also on the aspect of the structure of these organizations.

\section{CONCLUSION}

It is clear from my research, that the development of the sport sector didn't only had an effect on the value of the players and clubs, but with this raise in the amount of the resources, the need for development in the organizational background emerged. The Football Academy of Debrecen is a good example for this process. It had to expend the size and number of the departments to keep up with the competition realized on the market of the youth development. In addition to the organizational changes, it had to rationalize the processes also. It was crucial to appoint an operational director, and to separate the managing director role from the technical director. The disbandment of the daily work into departments created a transparent organizational structure what is the base of the proper operation. Besides the development of the company, there are significant differences compared to a profit-oriented enterprise. The base of this is the differences noticeable in the income structure. While the professional clubs need departments handling the marketing and financial planning, the academy has almost all of his income only from the owners and the federation. These departments have less weight in the structure of the academy, because the focus is on the development goals, so the importance of social, educational, and sport-science section grows. In summary I can say, that we can realize a constant development in the sector, and in accordance with this, we can also see an advance in the organizational questions of sport companies.

The publication is supported by the EFOP-3.6.2-16-201700003 project. The project is co-financed by the European Union under the European Social Fund.

\section{REFERENCES}

A. Chikán, (2003): Vállalatgazdaságtan. AULA Kiadó, Budapest ISBN: 963-9478-28-8

Bácsné B. É. (2015c): Examination of the organizational frameworks of sports enterprises in the light of good german practices. Apstract - applied studies in agribusiness and commerce, 9: 1-2 pp. 41-46.

Bácsné B. É. (2016/2): Futballvállalkozások lehetséges szervezeti formái nemzetközi jó gyakorlatok alapján -esettanulmány a Manchester United FC-ról (Az angol példa). TAYLOR: Gazdálkodás-és Szervezéstudományi Folyóirat: A Virtuális Intézet Közép-Európa kutatására Közleményei: 2016/2:(23) pp. 95-102.

Bácsné B. É. (2017): Magyar futballtársaságok szervezeti kérdései. Gazdálkodás-és Szervezéstudományi Folyóirat: A Vir- tuális Intézet Közép-Európa kutatására Közleményei: 2017, IX. (2 (28) pp. 5-13.

Bácsné B. É. (2015b): Sportszervezetek múködési kereteinek változása. KÖZÉP-EURÓPAI KÖZLEMÉNYEK 2015b, (No. 28) VIII. évf.1. pp. 151-161., 11 p.

Bácsné B. É. (2016/1): Szervezeti struktúra jellemzői spanyol labdarúgó kluboknál. Múszaki és Menedzsment Tudományi Közlemények 2016/1.: (1.) Paper 576a1603dab68. 9 p.

Bácsné B. É. (2015b): Szervezeti változások sikeres sportvállalkozások esetében. Taylor: Gazdálkodás- és szervezéstudományi folyóirat: A virtuális Interközép-Európa kutatására közleményei 2015b, 7.: 3-4. pp. 286-294., 9 p.

Dénes F. (1998): A futball eladásának közgazdasági alapjai, Marketing \& menedzsment ISSN 1219-0349

Ibrahim H. (2009): Sport and Society. An Introduction to Sociology of Sport. Whittier College, Whittier, California, 2 nd Printing. Chapter 6. Sport and Economics pp. 108-126

Paraszt I. (2008): Motiválás sportvezetôi módszerekkel. In: HR Portál http://www.hrportal.hu/hr/motivalas-sportvezetoi-modszerekkel-20081126.html

IEG Sponsorship Report, 2013 Sponsorship Outlook: Spending Increase Is Double-Edged Sword,

Bayer J. (2002): Globális média, Globális Kultúra. Magyar Tudomány, 2002./6.

András K. (2004): A hivatalos labdarúgás piacai, 53. számú tanulmány, Budapesti Közgazdaságtudományi és Államigazgatási Egyetem

András K. (2011): A hivatásos labdarúgás múködési modellje, Magyar Sporttudományi Füzetek III. - Sportágak versenye, pp. 18-42.

András K. (2003): A sport és az üzlet kapcsolata - elméleti alapok András Krisztina 34. sz. Mühelytanulmány, HU, ISSN 1786-3031, 2003

András K. (2002): Üzleti elemek a sportban, a hivatásos labdarúgás példáján, Doktori $(\mathrm{PhD})$ értekezés, BKÁE Gazdálkodástani PhD Program

Dajnoki K. (2015): A humán erőforrás gazdálkodás gyakorlata. Munkaerôpiaci és HR ismeretek. Debreceni Egyetem, Debrecen, ISBN: 978-615-80290-1-8

Kassay L. (2010): A szponzorok és reklámozók kiszolgálása, Marketing \& Menedzsment, Matarka, 32. évf. 3. sz. p. 25-27

Gálik M., Urbán J. (2009): Bevezetés a média-gazdaságtanba, Budapest, Aula Kiadó, ISBN: 978-9-6396-9842-0, 
Karoliny M., Poór J. (2010): Emberierőforrás-menedzsment. Complex Kiadó, Budapest, ISBN 9789632951089

Szabó M., Berde Cs. (2007): Az esélyegyenlőségi emberi erőforrás menedzsment (4EM) tevékenységterületei és feladatai, Campus Kiadó, Debrecen, 24 - 38.p

Ács P. (2015): Sport és Gazdaság, Pécsi Tudományegyetem Egészségtudományi Kar ISBN 978-963-642-372-8

Downward P., Dawson A., Dejonghe T. (2009): Sports economics, ISBN 978-0-7506-8354-8

Musinszki Z. (2012): Kontrolling alapjai, oktatási segédlet logisztikai menedzser és logisztikai mérnök mesterszakos hallgatók számára, Miskolc 